\title{
A reappraisal of the genus Megacaryon (Boraginaceae, Lithospermeae) based on molecular, morphological, and karyological evidence
}

\section{Federico Selvi, Lorenzo Cecchi, Hartmut H. Hilger \& Andrea Coppi}

To cite this article: Federico Selvi, Lorenzo Cecchi, Hartmut H. Hilger \& Andrea Coppi (2017) A reappraisal of the genus Megacaryon (Boraginaceae, Lithospermeae) based on molecular, morphological, and karyological evidence, Systematics and Biodiversity, 15:6, 552-563, DOI: 10.1080/14772000.2017.1290707

To link to this article: http://dx.doi.org/10.1080/14772000.2017.1290707

+ View supplementary material $\sqsubset$

曲 Published online: 01 Mar 2017.

Submit your article to this journal

Џ Article views: 43

Q View related articles 두

View Crossmark data \lceil 


\title{
Research Article
}

\section{A reappraisal of the genus Megacaryon (Boraginaceae, Lithospermeae) based on molecular, morphological, and karyological evidence}

\author{
FEDERICO SELVI ${ }^{1}$, LORENZO CECCHI ${ }^{2}$, HARTMUT H. HILGER ${ }^{3} \&$ ANDREA COPPI $^{4}$ \\ ${ }^{1}$ Università di Firenze, Dipartimento di Scienze delle Produzioni Agroalimentari e dell'Ambiente (DISPAA), Laboratorio di Botanica, P. \\ le delle Cascine 28, 50144 Firenze, Italy \\ ${ }^{2}$ Università di Firenze, Museo di Storia Naturale, sezione Botanica 'Filippo Parlatore', Via G. La Pira 4, 50121, Firenze, Italy \\ ${ }^{3}$ Freie Universität Berlin - Institut für Biologie - Systematische Botanik und Pflanzengeographie, Altensteinstr. 6, D-14195 Berlin, \\ Germany \\ ${ }^{4}$ Università di Firenze, Dipartimento di Biologia, Via G. La Pira 4, 50121, Firenze, Italy
}

(Received 30 June 2016; accepted 31 January 2017)

\begin{abstract}
The systematic position and phylogenetic relationships of Echium orientale, a rare endemic of the mountains of northern Turkey, were elucidated based on morphological, molecular, and karyological evidence.

Using nuclear and plastid DNA sequences, we found that this species is not included in Echium, but is rather at least as divergent from it as other related lineages, namely the South African Lobostemon and Echiostachys. Pollen characters revealed a strong affinity with Onosma, especially in the non-reticulate ornamentation of the tectum. Fruit morphology is unique in the genera of the Echium 'alliance' (e.g. Echium, Pontechium, Lobostemon, and Echiostachys), because of the large size and the smooth, glossy nutlet surface as in most species of Onosma. Karyological observations show that this species is diploid with $2 \mathrm{n}=12$, and differing from both Lobostemon or Echium, where nearly all species have higher numbers (usually $2 \mathrm{n}=14$ and $2 \mathrm{n}=16$, respectively). Combined with a 'megaherb' habit, the weak zygomorphism of the large flowers and a restricted range in the humid mountain forests of the Black Sea region, fruit, pollen and chromosome characters suggest an isolated position for E. orientale in the Echium alliance. We therefore propose its placement in the monotypic Megacaryon, a genus originally described by Boissier, but largely disregarded by later botanists. An original specimen is designated as generic lectotype.
\end{abstract}

Key words: karyology, molecular phylogenetics, monotypic genera, plant systematics, pollen morphology, Turkish flora

\section{Introduction}

With some 60 species, Echium L. is one of the largest genera of Boraginaceae tribe Lithospermeae, a group of c. 25 genera and 460 species occurring in Europe, Africa, Asia, and the Americas. Major diagnostic characters of Echium are the distinctly zygomorphic corolla, often with long exserted stamens of different lengths, and the more or less deeply divided style with two stigmatic branches (Gibbs, 1972; Johnston, 1924). Habit, life cycle and other vegetative characters are widely variable. The herbaceous habit is exclusive in the primary diversity centre in the west Mediterranean, continental Europe, and western Asia, while the woody, shrubby habit is characteristic of most Macaronesian endemic species that originated from mainland ancestors through a massive radiation in the Canary,

Correspondence to: Federico Selvi. E-mail: federico.selvi@unifi.it
Cape Verde, and Madeira islands (Böhle, Hilger, \& Martin, 1996; Mansion, Selvi, Guggisberg, \& Conti, 2009).

Closely related to Echium and initially considered congeneric are two South African endemic lineages, Lobostemon Lehm. and Echiostachys Levyns. Although Johnston (1924) initially included both in Echium because of continuous variation in floral characters, he later changed his opinion and accepted Lobostemon (including Echiostachys; Johnston, 1953). Subsequently, all authors have recognized both genera as distinct from Echium (Retief \& van Wyk, 1997; Weigend, Selvi, Thomas, \& Hilger, 2016) based on the location of the annulus 1.5-6 mm (vs. $<1 \mathrm{~mm}$ ) from base of corolla tube and the presence of five conspicuous densely pubescent bulges (Echiostachys) or scales (Lobostemon) borne below the filament attachment. Lobostemon includes some 30 species (Buys, 2006; Weigend et al., 2016) that are also distinguished from the three species of Echiostachys by the shrubby habit and the 
lack of a rosette of basal leaves (Levyns, 1934a; Retief \& van Wyk, 1997). Phylogenetic analyses have resolved these two genera as a clade that is the sister lineage to Echium (Cohen, 2014; Hilger \& Böhle, 2000).

Recently separated from Echium is the monotypic genus Pontechium Böhle \& Hilger, with its single species E. maculatum L. ( = E. russicum Gmel., = E. rubrum Jacq.) from eastern Europe and most of Russia. This taxon shows a more marked phylogenetic divergence from Echium than does the latter from either Lobostemon or Echiostachys, thus suggesting an earlier split of Pontechium from Echium than the two South African genera (Hilger \& Böhle, 2000). Morphologically, Pontechium is distinguished only by its undivided stigma, a character already used to place it in Echium section Holostigma K. Koch.

Based on the studies mentioned above, the biogeography, general phylogenetic relationships and major evolutionary trends of character variation in the Echium s.l. clade are today relatively well known. However, a few points still remain to be resolved, one of which concerns the affinities and the correct placement of Echium orientale L., a rare species endemic to the Black Sea region in northern Turkey (Edmondson, 1979). This species (Figs 1, 4) was first observed and illustrated by Tournefort (1717) during his trip to Asia Minor in 1701-1702 (Burtt, 2001,
2002), then formally described (Linnaeus, 1753) based on material cultivated from seeds probably collected by Tournefort himself (Mill in Cafferty \& Jarvis, 2004). More than one century later, Boissier (1875a) described the same species as Megacaryon armenum Boiss., therefore placing it in a new, monotypic genus. This was separated from Echium due to the only weakly zygomorphic corolla ('subregularis') without an annulus at the base, the very large fruiting calyx, and the single large-sized nutlet with a smooth, glossy surface, rather than trigonous-triquetrous and strongly tuberculate-scrobiculate seeds as in the great majority of Echium species. In his Flora Orientalis, Boissier (1875b) recognized that his species and E. orientale L. were conspecific and made the new combination Megacaryon orientale (L.) Boiss. Since then, however, Boissier's genus has been recognized only by Gürke (1895), while it was sunken in Echium by all other authors (e.g. Edmondson, 1979; Greuter, Burdet, \& Long, 1984; Heller \& Heyn, 1986) who followed Johnston's (1953) opinion of not accepting it.

However, the phylogenetic affinity of this diverging endemic has never been tested, probably due to its rarity and the consequent difficulty in obtaining material for more in-depth investigations. During a recent field trip to this area we had the opportunity to observe native populations and to
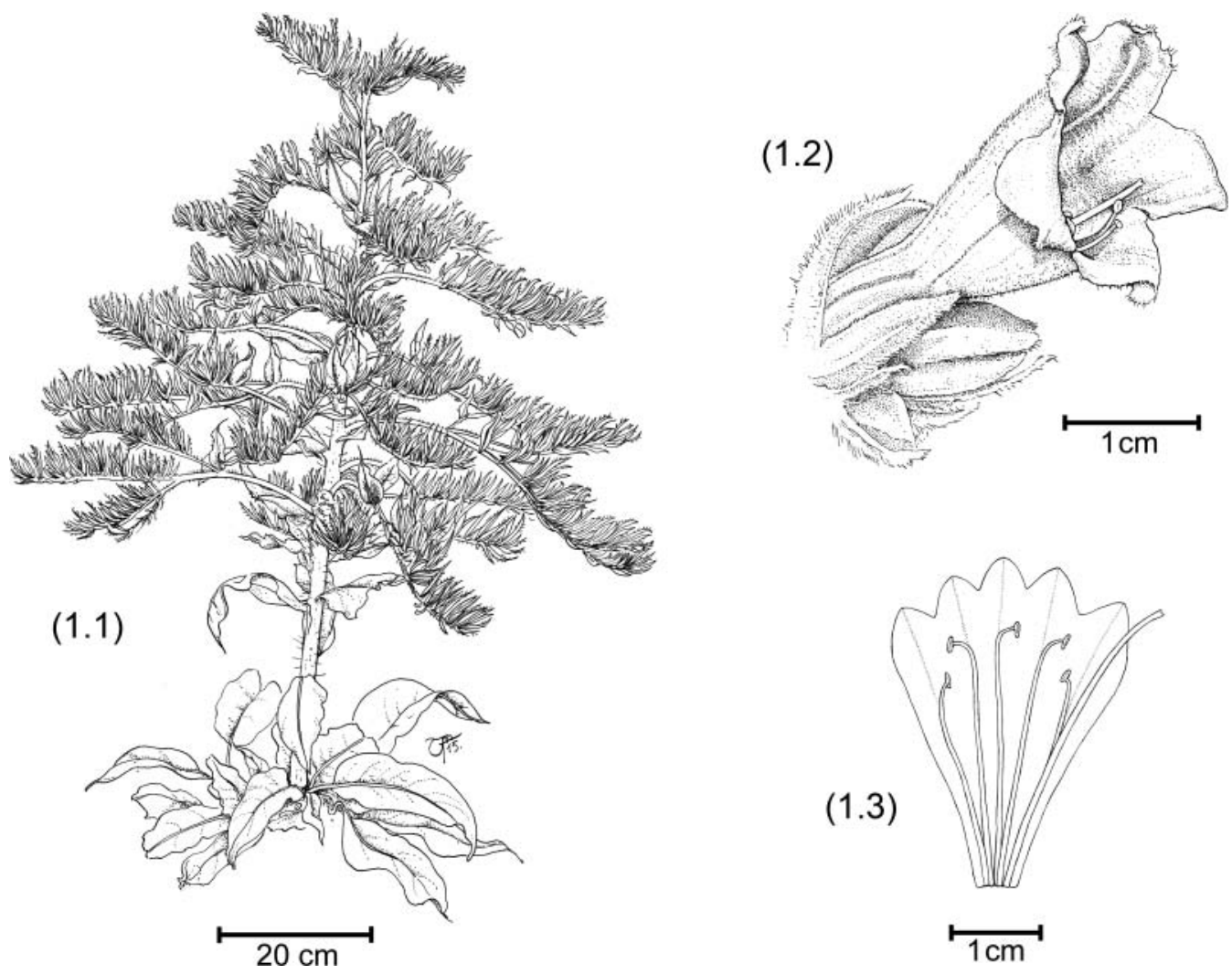

Fig. 1. Megacaryon orientale (L.) Boiss. (Cecchi \& F. Selvi HB 15.14, FIAF). (1.1) habit; (1.2) flower; (1.3) open corolla. Original drawing by Laura Vivona. 
collect material for a study of its phylogenetic affinities and taxonomic position based on morphological, karyological, and molecular tools. The results bring new evidence suggesting the resurrection of Boissier's Megacaryon, thus allowing the systematics and taxonomy of Echium s.l. and of tribe Lithospermeae to be refined.

\section{Materials and methods}

\section{Plant material}

Native populations of E. orientale were studied and sampled by the authors in summer 2015 in two distinct mountain localities of the Black Sea region of northern Anatolia, Turkey. The first (Cecchi \& Selvi HB 15.14, FI, FIAF) was located in the mountains around lake Abant (Bolu province), while the second (Cecchi \& Selvi HB 15.17, FIAF) was found on the Ilgaz mountain chain between Kastamonu and Ilgaz (Kastamonu province); both populations were localized in small patches in clearings of extensive Abies nordmanniana-Fagus orientalis forests, at $1050 \mathrm{~m}$ and $1500 \mathrm{~m}$ a.s.l. respectively. Herbarium specimens kept in FI were also studied. Additional material of Echium, Pontechium, Lobostemon, and Onosma was obtained from personal collections in various Mediterranean countries and Canary Islands, housed in FIAF and FI.

\section{DNA extraction and amplification}

Genomic DNA of E. orientale was extracted from silicagel dried samples of leaf tissue using a modified $2 \mathrm{xCTAB}$ protocol (Doyle \& Doyle, 1990). Amplification of the ITS region, including ITS1, 5.8S, and ITS2, the $\operatorname{trn} \mathrm{L}_{(\mathrm{UAA})}$ intron and of the trnL-trn $\mathrm{F}$ intergenic spacer followed the procedures described in Böhle et al. (1996) and Cecchi, Coppi, Hilger, and Selvi (2014). These three markers were selected for their phylogenetic signal in this group of Boraginaceae-Lithospermeae, at the species and genus level (Hilger \& Böhle, 2000).

Automated DNA sequencing was performed directly on the purified PCR products using BigDye Terminator v.2 chemistry and an ABI310 sequencer (PE-Applied Biosystems, Norwalk, CT, USA).

\section{Sequence alignment and phylogenetic analyses}

Novel sequences of E. orientale were processed as described in Cecchi et al. (2014). Two datasets were initially prepared for phylogenetic analyses (ITS and trnL$\operatorname{trn} \mathrm{F}$ ) with other sequences retrieved from International Nucleotide Sequence Data Collaboration (INSDC; Appendix 1, see online supplementary material, which is available from the article's Taylor \& Francis Online page at http://dx.doi.org/10.1080/14772000.2017.1290707). The resulting ITS dataset was formed by 56 ingroup taxa representing the great majority of old-world Lithospermeae (23 genera from the Mediterranean, Africa, and Asia). All Macaronesian and continental species of Echium for which ITS data were available from INSDC were included in this dataset, as well as representatives of Lobostemon, Echiostachys, and Pontechium. The Onosma s.l. clade was represented by 10 Onosma species (Mediterranean and Asiatic), and representatives of the genera Cystostemon and Maharanga from Africa and Asia, respectively. The $\operatorname{trn} \mathrm{L}-\operatorname{trn} \mathrm{F}$ dataset included all 11 ingroup taxa of the Onosma-Echium lineage for which full sequences (c. $900 \mathrm{bp}$ ) were available from INSDC (Appendix 1). Although taxon sampling was much reduced compared with ITS, all genera in the group under study except for Echiostachys were included in this analysis, providing additional evidence on the position of $E$. orientale. Finally, we prepared and analysed a combined

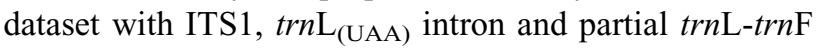
sequences (c. $350 \mathrm{bp}$ ) of 30 ingroup species, of which 25 were members of Echium included in the study by Hilger and Böhle (2000).

The full list of accessions used in this work is reported in Appendix 1 (see online supplementary material) and all three alignments are available from the authors upon request.

Multiple alignments were performed with MAFFT v. 7.0 (Katoh \& Standley, 2013) using the G-INS-1 strategy which is an accurate iterative refinement method recommended for small-scale alignments (Katoh, Kuma, Toh, \& Miyata, 2005). Gaps were coded as separate characters according to Simmons and Ochoterena (2000) using FastGap v.1.2 (Borchsenius, 2009) and appended at the end of the datasets.

Phylogenetic analyses were performed using Maximum Parsimony and Bayesian methods. Taxa of subfamily Echiochiloideae Weigend and subfamily Boraginoideae Arn. tribe Boragineae Rchb. were selected as outgroup representatives, based on their relationships to Lithospermeae (Chacón et al., 2016; Weigend, Luebert, Selvi, Brokamp, \& Hilger, 2013).

Tree construction was first performed using PAUP 4.0 (Swofford, 2000), running heuristic searches with 'treebisection-reconnection' (TBR) branch-swapping with accelerated transformation (ACCTRAN) optimization to infer branch (edge) lengths; MULTREES option on, ADDSEQ $=$ random, 20 randomized replicates. All characters were weighted equally, and character state transitions were treated as unordered; gaps in the alignment were treated as missing data. Bootstrap support for clades was obtained performing a heuristic search with 1000 replicates, using TBR branch-swapping, 10 random taxon entries per replicate and MULTREES option on. 
Bayesian inference of phylogeny was performed with MrBayes 3.1.2 (Ronquist \& Huelsenbeck, 2003). The GTR + G and HKY + G substitution models were identified by FindModel (available at: http://www.hiv.lanl.gov/ content/sequence/findmodel/findmodel.html) as the bestfitting models for respectively the ITS and the combined dataset (excluding gap characters in both cases), based on the Akaike Information Criterion.

The analyses were performed using four incrementally heated Markov chains (one cold, three heated) simultaneously started from random trees, and run for one million cycles sampling a tree every 10 generations. The stationary phase was reached when the average standard deviation of split frequencies reached 0.01 . Trees that preceded the stabilization of the likelihood value (the burn-in) were discarded, and the remaining trees were used to calculate a majority-rule consensus phylogram. The trees were viewed and edited with TreeView (Page, 1996).

\section{Micromorphology (SEM)}

Pollen grains from dry specimens were rehydrated in a solution of Aerosol-OT 20\% and then observed with a scanning electron microscope (FEI ESEM-QUANTA 200 ) working at $30 \mathrm{kV}$. Nutlets were directly mounted on stubs, without gold sputtering, and observed at the SEM.

\section{Karyology}

Root tips from a 6-month-old plant grown from seeds of one of the two populations were collected in May 2016, and pre-treated with $0.002 \mathrm{M}$ 8-hydroxyquinoline for 2 hours at room temperature and then fixed overnight in ethanol:glacial acetic acid 3:1 (Bigazzi \& Selvi, 2001). When necessary, they were preserved in $70 \%$ ethanol at 3$4^{\circ} \mathrm{C}$ until preparation. For standard analysis they were then rinsed in distilled water, hydrolysed in $1 \mathrm{~N} \mathrm{HCl}$ at $60^{\circ} \mathrm{C}, 6$ $7 \mathrm{~min}$, stained in lacto-propionic orcein overnight, dissected and squashed on clean glass slides in a drop of $45 \%$ acetic acid. Metaphase plates were examined with a Zeiss Axioscop light microscope under oil immersion $(\times 100)$, and photographed with a Nikon digital system.

\section{Results}

\section{Nuclear ITS-5.8S dataset}

The aligned matrix included a total of 864 positions, with coded gaps in positions $693 \sim 864 ; 171$ indels were present in the alignment and the length of gaps ranged from 1 to 12 positions. In the Maximum Parsimony analysis, 240 characters were constant and 424 were parsimony informative. The high rate of ITS sequence variation (nearly $50 \%$ ) was not surprising, due to the phylogenetic distance between the taxa of Lithospermeae in our dataset and the inclusion of members of tribe Boragineae and subfamily Echiochiloideae as outgroup representatives (see Chacón et al., 2016).

The heuristic search produced 32 most parsimonious trees with $\mathrm{L}=2133$, Consistency index $(\mathrm{CI})=0.57$ and Retention index $(\mathrm{RI})=0.71$. The strict consensus was topologically largely congruent with the majority-rule consensus tree produced by the Bayesian analysis (Fig. 2.1). Kimura two-parameters pairwise genetic distances, within and between genera in the Echium s.l. group and Onosma are reported in Table 1. The Echium s. 1. clade, including all species of Echium, Pontechium, Lobostemon and Echiostachys, resulted monophyletic with good support ( $89 \%$ BS, $0.97 \mathrm{PP}$ ) and was sister to the Onosma s.l. clade (79\% BS, 0.96 PP). Pontechium was the first diverging lineage within the Echium s.l. group within which Echium was not retrieved as monophyletic because of the position of E. orientale which was resolved as sister group (69\% BS, $0.92 \mathrm{PP})$ to a moderately supported clade comprising Echium s.s. (i.e. excluding E. orientale), Lobostemon and Echiostachys (92\%, $0.92 \mathrm{PP})$. Echium orientale differed from all members of the Echium and Onosma clades by 13 single nucleotide polymorphisms (SNPs) and 1-bp deletions. The affinity between the South African Lobostemon and Echiostachys was strongly corroborated (100\% BS, $0.99 \mathrm{BS})$, as well as the monophyly of Echium s.s. (98\% BS, 0.99 PP) including the group of the Macaronesian endemics $(100 \%$ BS, $0.99 \mathrm{PP})$. The mean genetic distance of E. orientale to the other Echium species was $c$. three time higher than that between these latter species (0.134 vs. 0.045; Table 1). The Onosma s.l. clade was strongly supported (100\% BS, 0.99 PP), and the African Cystostemon was the first diverging lineage. The rest of this clade showed an early split in two major subclades, one with Maharanga emodi and the two Chinese species $O$. waltonii and $O$. paniculata ( $98 \%$ BS, $1.00 \mathrm{PP}$ ), and the other with the bulk of Mediterranean-Irano-Turanian Onosma species $(100 \%$ BS, $1.00 \mathrm{PP})$. The other major groups were those of Huynhial Neatostema/Cerinthe/Moltkiopsis/Mairetis/Halacsya/Paramoltkia/Lithodora (clade B), Lithospermum/Glandoral Buglossoides/Aegonychon (clade C), Moltkia (clade D), Arnebia (clade E) and Alkanna/Podonosma (clade F).

\section{Plastid trnL-trnF IGS dataset}

The complete alignment was 935 bp long (including gaps in pos. 906-935) and included 94 variable characters $(10 \%)$; of these, only 46 were parsimony informative. The Bayesian phylogram (Fig. 2.2) was topologically congruent with ITS in retrieving two strongly supported clades: that of Onosma s.l. (95\% BS, $1.00 \mathrm{PP}$ ) and that of Echium s.1. (1.00 PP, $89 \%$ BS). In the former Maharanga was clearly sister to Onosma (100\% BS, $1.00 \mathrm{PP})$, while in the 


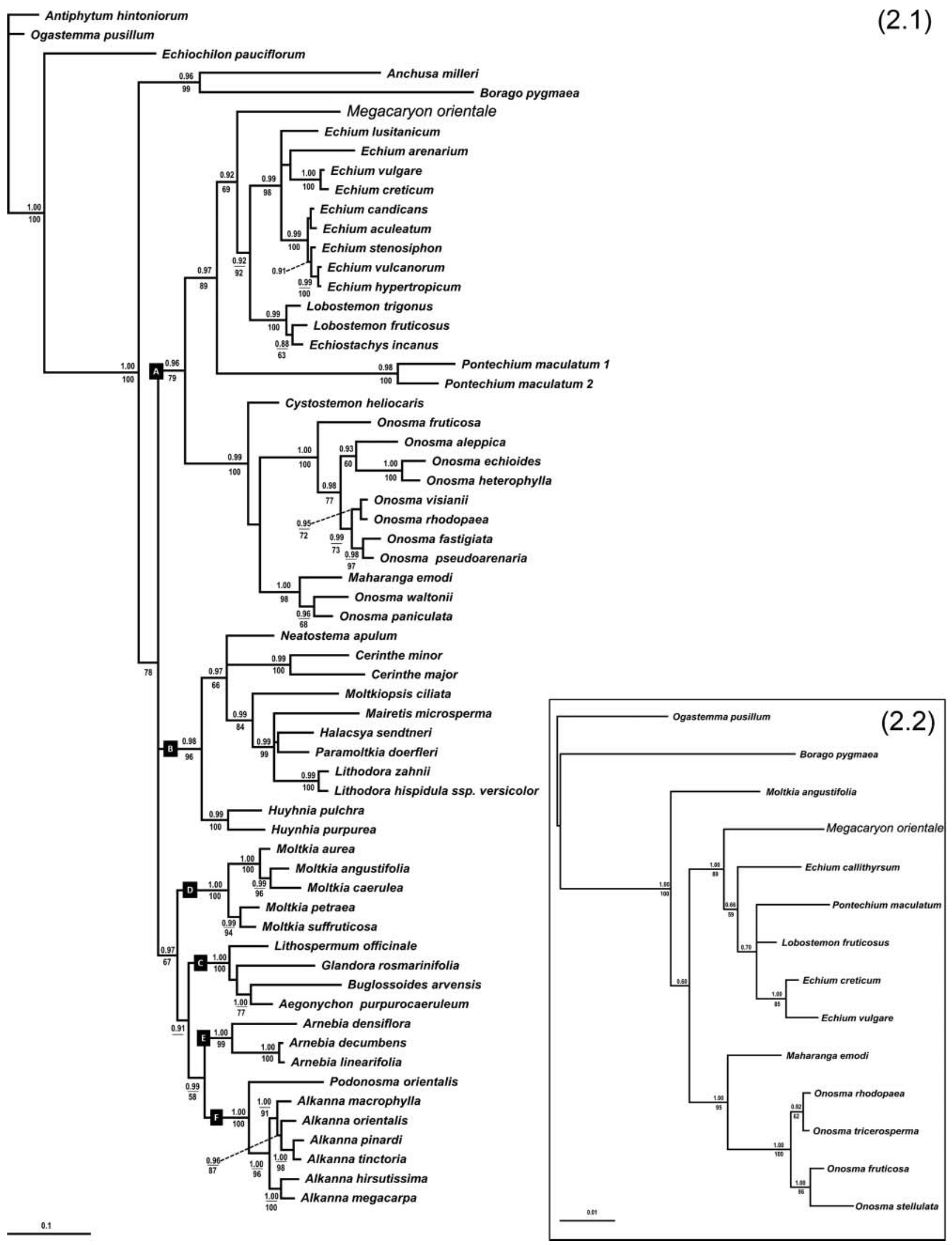

Fig. 2. Consensus phylograms (50\% majority-rule) from Bayesian analysis of: (2.1) nuclear ITS-5.8S sequences, and (2.2) plastid trnLtrnF sequences. Posterior probability (PP) and bootstrap support (BS) values are shown near statistically supported nodes; the main clades of Lithospermeae are indicated with black squares and letters, according to Cecchi and Selvi (2009). 
Table 1. Mean genetic distances (lower-left half of the table), between species of the same genus (within genera) and between genera, based on ITS-5.8S DNA sequences and calculated according to Kimura (1980); standard errors are shown in the upper-right half of the table.

\begin{tabular}{lccccccc}
\hline & & \multicolumn{6}{c}{ between genera } \\
\cline { 3 - 8 } Genus & within genera & Echium & Lobostemon & Echiostachys & Pontechium & Megacaryon & Onosma \\
\hline Echium & 0.045 & - & 0.012 & 0.016 & 0.016 & 0.013 & 0.014 \\
Lobostemon & 0.026 & 0.101 & - & 0.006 & 0.028 & 0.015 & 0.021 \\
Echiostachys & - & 0.104 & 0.020 & - & 0.043 & 0.020 & 0.030 \\
Pontechium & - & 0.204 & 0.301 & 0.416 & - & 0.017 & 0.017 \\
Megacaryon & - & 0.134 & 0.131 & 0.133 & 0.202 & - & 0.018 \\
Onosma & 0.062 & 0.183 & 0.216 & 0.241 & 0.243 & 0.218 & - \\
\hline
\end{tabular}

latter E. orientale, E. callianthemum, Pontechium and Lobostemon formed, in that order, a 'grade' relative to the clade comprising E. creticum and E. vulgare (100\% BS, $1.00 \mathrm{PP}$ ). Low support values for the corresponding nodes suggested substantially unresolved relationships between the five branches above, but again E. orientale did not cluster with the two species of Echium s. s. and it differed from all other members of the Onosma s.l. and Echium s.l. clades by 13 SNPs, 1-bp deletion and 1-bp insertion.

\section{Combined dataset}

The combined alignment included 1144 positions (ITS1: 1 257, trnL intron: 258 760; trnL-trnF, partial: 761 1109; coded gaps: 1110 1144). Maximum Parsimony search produced 47 trees $(\mathrm{L}=425, \mathrm{CI}=0.76$, RI $=0.81$ ), the strict consensus of which (Fig. 3) was topologically congruent with the phylogram resulting from Bayesian analysis of the sequence data (excluding coded gap characters). Pontechium was confirmed as the sister to the rest of the Echium alliance ( $96 \%$ BS, 0.99 PP), including E. orientale and the Lobostemon-Echiostachys clade ( $98 \%$ BS, $0.97 \mathrm{PP})$. Here, the placement of E. orientale as sister to the group of Lobostemon-Echiostachys + Echium s.s. was not well supported (60\% BS), leaving the relationships between these three lineages substantially unresolved. However, both E. orientale and the two South African genera were clearly resolved outside of a monophyletic Echium s. str. ( $85 \%$ BS, $0.97 \mathrm{PP})$.

\section{Fruit and pollen morphology}

Major characters of fruit morphology such as general shape, surface, ventral keel (carpel suture) and basal attachment on the flat gynobase are basically uniform in the 'Echium alliance' and Onosma s.l. Detailed descriptions of these characters were already given in previous studies, especially Johnston (1953) and Seibert (1978).
Field observations of numerous individuals of both populations of $E$. orientale showed that the early abortion of three (rarely two) nutlets is the rule in this species, explaining the occurrence of only one diaspore (or rarely two) in the fruiting calyx (Fig 4.3). This phenomenon is only exceptional in the other genera examined here, where the smaller size of each single nutlet allows their regular development towards maturity as is typical for most Boraginaceae.

All species of Echium, Lobostemon, Echiostachys, and Pontechium, show small or medium-sized trigonous-triquetrous eremocarps (sensu Hilger, 2014) with a slightly incurved body and a highly elaborated surface bearing more or less prominent tuberculate-scrobiculate processes throughout, especially in some endemics of the Macaronesian islands (Fig. 5.3-5.6). Echium orientale differs from these species in the much larger size $(c .7 .5 \times 6 \mathrm{~mm}$, from which Boissier's name 'Megacaryon'), the wider ovoidsubglobose shape, faintly beaked apex, and the nearly smooth, glossy surface without tuberculate-scrobiculate processes (Fig. 5.1). In these characters it clearly resembles the species of Onosma, whose nutlets differ from those of E. orientale only in their smaller size (Fig. 5.2).

Palynological observations added further elements of systematic relevance. Grains of E. orientale present the basic traits of Echium, Lobostemon, Echiostachys, and Pontechium maculatum (this apparently shown here for the first time), as well as Onosma, in being relatively small-sized (mean $\mathrm{P}=15.2 \mu \mathrm{m}$, mean $\mathrm{E}=11.1 \mu \mathrm{m}$ ), subprolate to slightly prolate $(\mathrm{P} / \mathrm{E}=1.37)$, heteropolar and ovate-triangular in equatorial view, with three fusiform ectoapertures along the sides, free at ends, and covered with conical gemmae (Table 2; Fig. 6.1-6.7); each ectoaperture bearing a protruding, circular endoaperture situated close to the broader pole and with a gemmate surface. However, a major difference of $E$. orientale with respect to other taxa in the Echium s.l. group was observed in the ornamentation of the tectum, that was punctate-perforate rather than reticulate to micro-reticulate as in Echium (Fig. 6.5, 6.6), Lobostemon, and Echiostachys. 


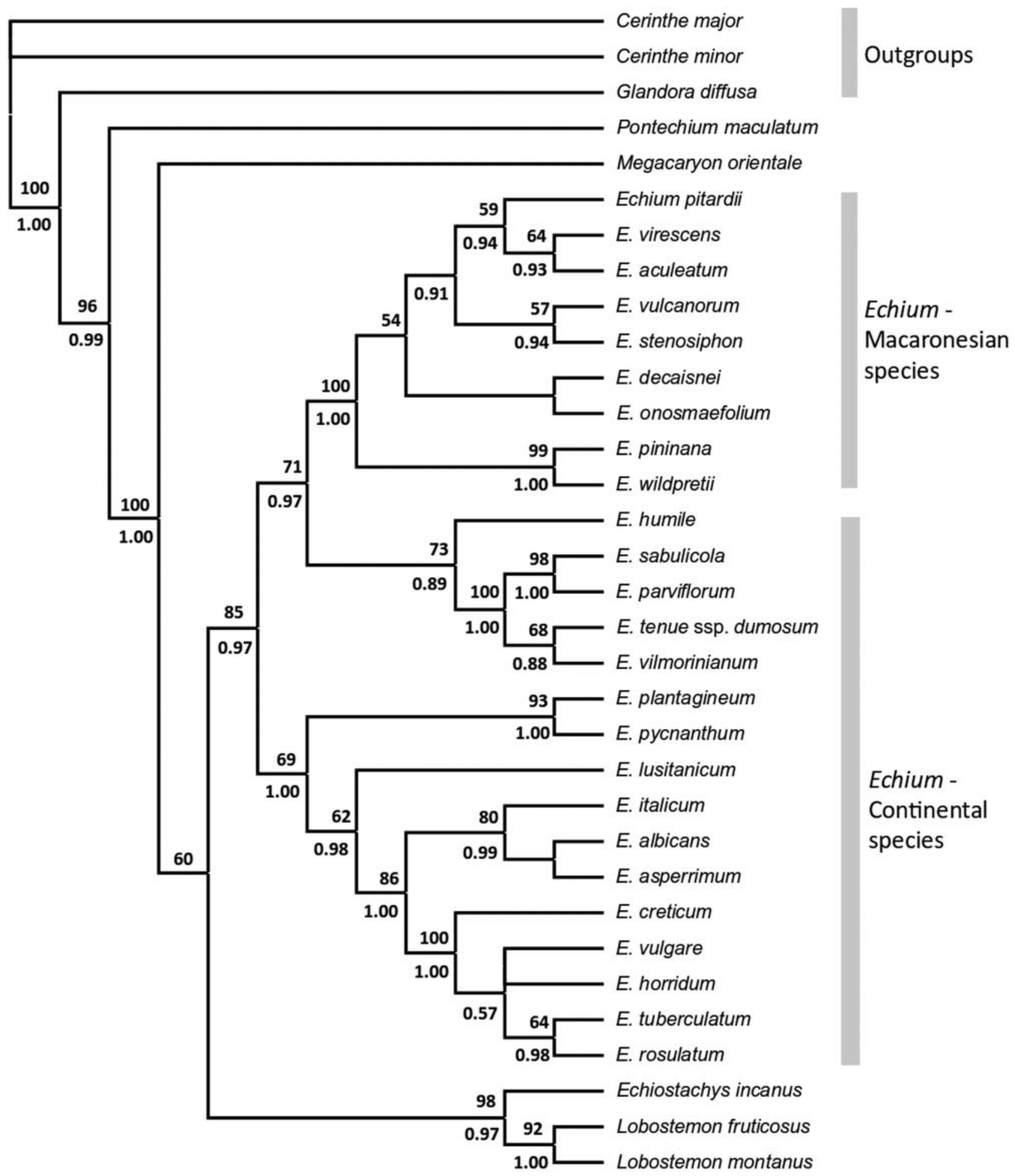

Fig. 3. Strict consensus from Maximum Parsimony analysis of the Echium 'alliance' with bootstrap support and Bayesian posterior probabilities, based on the combined ITS1, $\operatorname{trn} \mathrm{L}_{\mathrm{UAA}}$ intron, and $\operatorname{trn} \mathrm{L}-\operatorname{tr} n \mathrm{~F}$ (partial) sequence dataset.

Interestingly, this character also occurs in most Mediterranean taxa of Onosma (Fig. 6.3), whose grains appeared remarkably similar to those of E. orientale and belong to the same type.

\section{Karyology}

Observations on the population from the Ilgaz mountains showed this species to be diploid with $2 \mathrm{n}=2 \mathrm{x}=12$. Metaphase chromosomes were small-sized (length range 


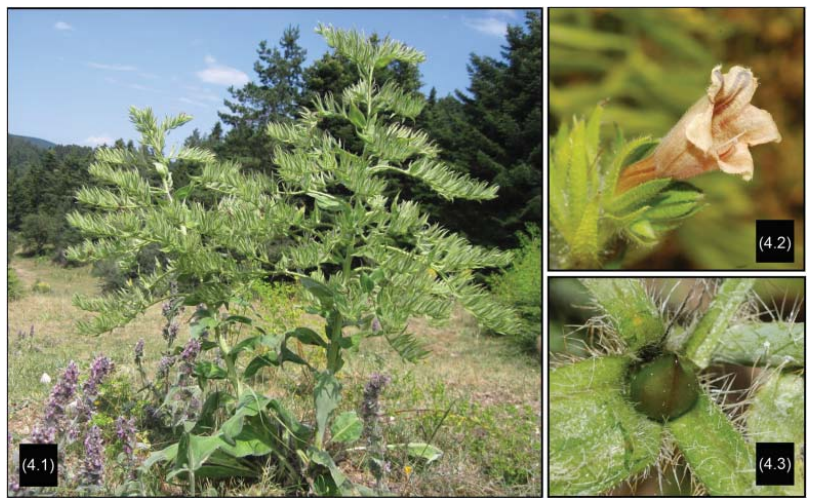

Fig. 4. Megacaryon orientale. (4.1) whole plant in its natural habitat; (4.2) flower; (4.3) fruiting calyx showing the single developing nutlet. Photos L. Cecchi (4.1) and F. Selvi (4.2, 4.3).

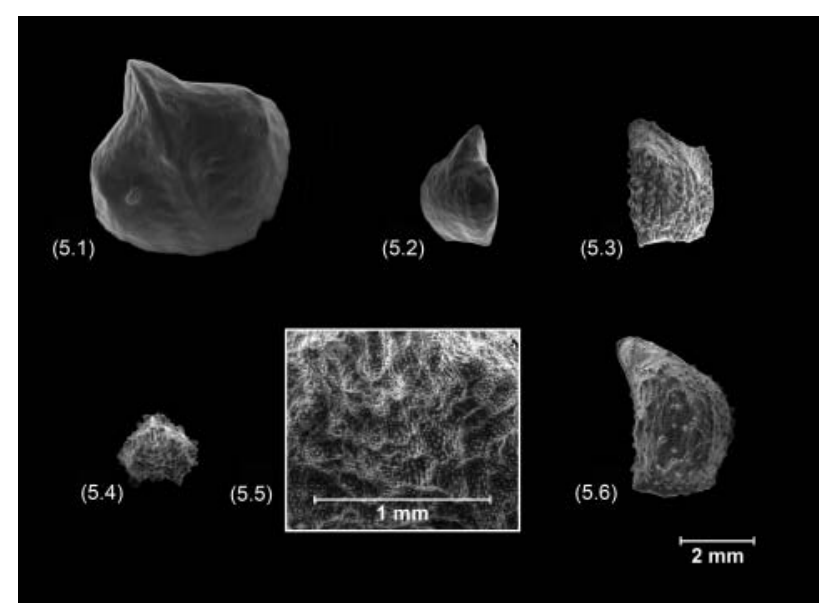

Fig. 5. SEM micrographs of fruit. (5.1) Megacaryon orientale (Cecchi \& Selvi HB 15.14, FIAF); (5.2) Onosma heterophylla (Cecchi \& Selvi HB 08.02, FIAF); (5.3) Lobostemon trigonum (Drége 446, FI); (5.4, 5.5) Echium wildpretii (Selvi HB 13.81, FIAF); (5.6) Pontechium maculatum (Cecchi, Coppi \& Selvi HB 06.07, FIAF).

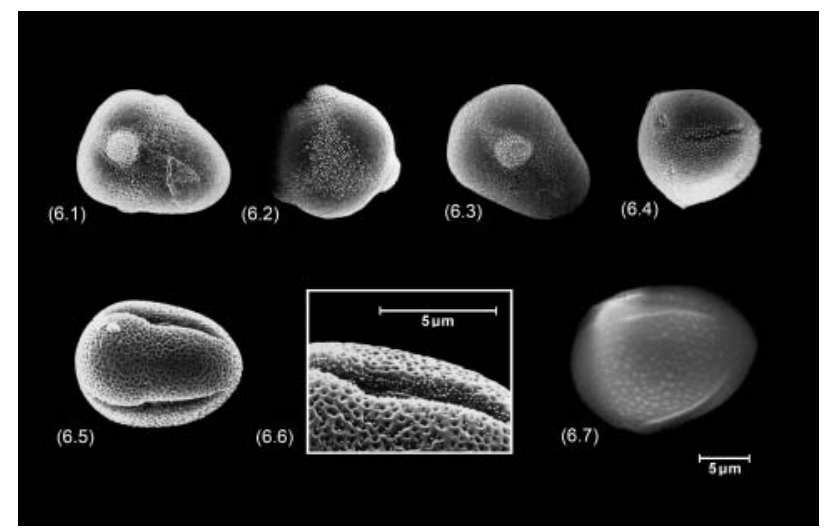

Fig. 6. SEM micrographs of pollen grains. (6.1-6.2) Megacaryon orientale, equatorial and polar view, respectively (Sintenis 4159, FI); (6.3-6.4) Onosma auriculata DC., equatorial and polar view, respectively (Bigazzi \& Selvi HB 96.19, FIAF); (6.5-6.6) Echium anchusoides Bacchetta, Brullo et Selvi (Bacchetta \& Selvi HB 99.26, FIAF); (6.7) Pontechium maculatum (Cecchi, Coppi \& Selvi HB 06.07, FIAF).

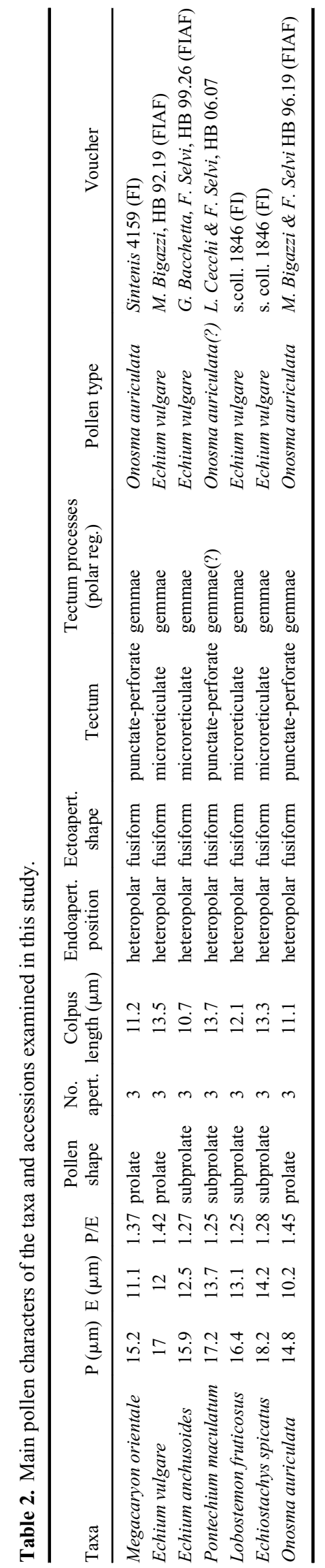




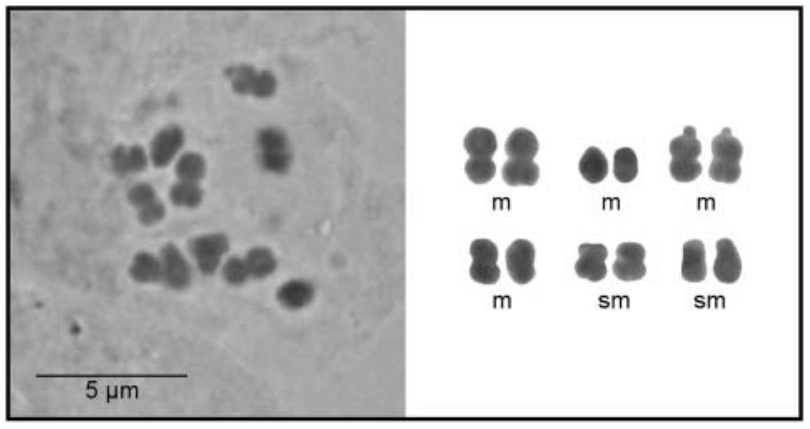

Fig. 7. Micrograph of a chromosome metaphase plate and karyotype of the population from the Ilgaz mountains (Kastamonu province) $; \mathrm{m}=$ metacentric, $\mathrm{sm}=$ submetacentric chromosome pairs.

c. $1.5-2.8 \mu \mathrm{m}$ in length) and of metacentric (four pairs) to sub-metacentric type, with a homologue pair of submetacentrics provided with macro-satellites on the short arms (Fig. 7). One pair of metacentrics was considerably larger than all other pairs.

\section{Taxonomy}

Megacaryon Boiss

Pl. Or. Nov. Dec. 1: 7. 1875.

Type: Megacaryon armenum Boiss. Megacaryon orientale (L.) Boiss., Fl. Or. 4: 204. 1875.

$\equiv$ Echium orientale L., Sp. Pl. 1: 139. 1753.

Locus classicus: 'Habitat in Oriente'; described from cultivated material perhaps derived from seed collected by Tournefort in Asia Minor (Turkey). Lectotype (iconotype, designated by Mill in Cafferty \& Jarvis, 2004: 802): 'Echium orientale, verbasci folio, flore maximo campanulato', drawing in Tournefort (1717: page opposite to 248; http://gallica.bnf.fr/ark:/12148/bpt6k10575681/f285).

Tournefort's description was discussed in detail by Burtt (2002) who also reproduced an illustration of the subsequently designated lectotype (Burtt, 2001).

= Megacaryon armenum Boiss., Pl. Orientate. Nov. (dec. prim.): 7. 1875.

Locus classicus: [Turkey, Trabzon] 'in arvis incultis Armeniae Turcicae prope Macka'. Lectotype (designated here): 'Onosma megalosperma ['megulospermum' in Boissier, 1875a], spec. nova [...] champs incultes prés Macka', 02 Aug 1862, E. Bourgeau no. 481 (G-BOIS, G00330651, photo! Isolectotypes: FI010649!, http://parla tore.msn.unifi.it/types_new/search.php; P00599751, photo!, https://science.mnhn.fr/institution/mnhn/collec tion/p/item/p00599751; P00599752, photo!, https://sci ence.mnhn.fr/institution/mnhn/collection/p/item/ p00599752).

\section{Discussion}

By combining molecular, morphological, and karyological data, the present work contributes to the knowledge of a rare endemic species whose affinities have been uncertain for long time. Although relationships in Echium s.l. were largely known thanks to previous phylogenetic studies focusing on it (Böhle et al., 1996; Hilger \& Böhle, 2000), old-world Lithospermeae (Cecchi \& Selvi, 2009) or Boraginaceae (Cohen, 2014; Mansion et al., 2009; Weigend et al., 2013), our findings add elements that may lead to a better definition of the generic units in this clade and allow us to resurrect Megacaryon.

The molecular markers used in this study are congruent in showing that Megacaryon is either outside the clades of Echium (s.str.) and Lobostemon-Echiostachys, or without direct affinity to Pontechium, the other monotypic genus in the lineage and probably sister to the rest of the Echium alliance. While the ITS phylogeny suggests that Megacaryon diverged from Echium s. str. earlier than the two south African genera, this relationship was not fully supported in the combined analysis, leaving the identity of the sister group to Echium still uncertain. Further analyses with more markers may help to address this issue.

Morphology supports the somewhat isolated position of M. orientale. Given its tall stature and very large basal leaves (up to $65 \times 30 \mathrm{~cm}$ ), this endemic displays a 'megaherb-like' habit similar to that of other Boraginaceae found in the humid mountain forests of the southern Black Sea region such as Brunnera macrophylla (Adams) I.M. Johnst. and Trachystemon orientalis (L.) G. Don. Although it is reported to have a biennial life cycle (Edmondson, 1979; Johnston, 1953) our field observations would rather support a perennial habit, like that of the other two forest herbs mentioned above, and as already indicated by Boissier (1875a) for Megacaryon armenum. Observation of plants currently in cultivation will hopefully help to address this issue. In any case, other continental herbaceous species of Echium rarely reach such size, especially in the size of the basal leaves, while the large-sized Macaronesian endemics differ mainly by their woody, shrubby habit, which is also found in South African Lobostemon.

Morphology of reproductive structures provides further support for the distinctiveness of Megacaryon. As already observed by Boissier (1875a, b), floral zygomorphism in this species is less pronounced than in most true Echium. The corolla is not as distinctly bilabiate, and the calyx even less, while the androecial arrangement is similar in having stamens filaments of different lengths but they are inserted at approximately the same height in the lower part of the corolla wall. Even more distinct is the fruit, usually composed at maturity by only one or two nutlets. Abortion is probably associated with their large size, which prevents the full development of the four 
eremocarps which is the rule in the Boraginaceae (Hilger, 2014). Reduction to a single nutlet was already highlighted by Seibert (1978) who also reported the lack of calcium carbonate incrustations in the pericarp of this species, a feature shared with most other species of Echium. On the other hand, all species of Echium, Lobostemon, Echiostachys, and Pontechium are characterised by a strongly sculptured and rough pericarp, which is in contrast to the nearly smooth, glossy surface of $M$. orientale. In this character and with the wide-ovoid shape (not trigonous-pyriform), this endemic shows a remarkable resemblance to Onosma, whose nutlets differ only in their generally smaller size and presence of calcium in the pericarp (Seibert, 1978). This explains why Boissier (1875a), who received only fruiting material of $M$. armenum from Bourgeau, initially referred this species to Onosma and named it 'O. megalosperma' on herbarium sheets labels (1875a: 8).

Pollen morphology is often a valuable source of information in the systematics of Lithospermeae because of the wide variation and phylogenetic signal, especially at the genus level (Cecchi \& Selvi, 2009; Johnston, 1953; Liu, Li, Zhang, \& Ning, 2010; Weigend, Gottschling, Selvi, \& Hilger, 2009). Numerous species of Echium, Lobostemon, and Echiostachys have been investigated in previous works (e.g. Johnston, 1953; Reille, 1992, 1995; Retief \& van Wyk, 1997), but none of these included M. orientale. Our observations confirmed this species and Pontechium maculatum to be palynologically close to the genera mentioned above and to Onosma, in their small-sized, heteropolar (pear-shaped) grains with three narrow ectoapertures free at ends, each provided with a circular endoaperture close to the broader pole. Onosma and Echium differ mainly in the tectum ornamentation, which is punctate-perforate, more or less scabrate to rugulate in the former (see also Binzet, Erkara, Özler, \& Pehlivan, 2014) and reticulate, microreticulate to foveolate in the latter. This character has been considered 'evolutionarily more advanced' (Liu et al., 2010), while M. orientale, and apparently Pontechium as well, are clearly closer to Onosma in their nearly smooth tectum that may represent the plesiomorphic condition in the Onosma-Echium s.l. clade.

Additional considerations can be made based on chromosomal features. Megacaryon orientale is a diploid species with one of the lowest base numbers known in tribe Lithospermeae $(\mathrm{x}=6)$. The same number is characteristic of Pontechium maculatum, which is however tetraploid with 2n $=24$ (Letz, Uhríková, \& Májovský, 1999; Markova, 1983) and, in the Onosma-Echium clade, of a few species of Onosma such as the west Mediterranean $O$. fastigiata (Braun-Blanq.) Braun-Blanq. ex Lacaita (Galland, 1988), the west Asian O. hispida Wall. ex G. Don (Kaul $\&$ Bindroo, 1984) and the Greek O. spruneri Boiss. (Teppner, 1996). The base number $\mathrm{x}=7$ is typical of South African Lobostemon (Levyns, 1934b), many species of
Onosma, and E. asperrimum Lam. within Echium (Luque, 1984). Since all other species of Echium investigated to date are diploid or tetraploid with $\mathrm{x}=8$ (with the only exception of Iberian E. boissieri Steud., $2 \mathrm{n}=10$; Luque, 1984), the hypothesis has been formulated that this is the basal chromosome number in the group and that all lower numbers have originated secondarily by descending mechanisms (Bramwell, 1973; Fritsch, 1973; Luque, 1984). Although this does not match the apparently more basal position of the lineages with $\mathrm{x}=6$ (Pontechium and M. orientale) and $\mathrm{x}=7$ (Lobostemon) in our phylogenetic reconstruction, it still remains a plausible assumption also in the light of similar descending trends in other groups of Boraginaceae (see, e.g., Selvi \& Bigazzi, 2002). Whatever the case, $M$. orientale is at present the only species in the Echium 'alliance' with $2 n=12$, which shows its uniqueness also on karyological grounds.

Based on the elements discussed above, this species seems to be characterized by a peculiar combination of traits which are partly typical of Onosma (pollen, fruit, partly chromosome complement) and partly of Echium, possibly representing a 'living proof' of the phylogenetic affinity between these two genera belonging to the same major lineage of Lithospermeae ('clade A' in Cecchi \& Selvi, 2009). Characters of the habit, fruit, pollen and possibly chromosome complement are likely plesiomorphic, and may have been retained from a common ancestor to the whole Onosma-Echium lineage.

Taxonomically, our findings suggest that Echium is nonmonophyletic if the species is included as E. orientale. It diverges from the rest of Echium at least as early as the South African lineages of Lobostemon and Echiostachys, both of which are today widely accepted genera (see also Weigend et al., 2016). The broad range disjunction between these two latter taxa and Echium, versus the sympatry of M. orientale with respect to various Echium species, would not be a good argument to recognize them while disregarding the overall greater distinctiveness of this Turkish endemic. Although further phylogenetic research with more molecular markers may bring new elements and improve resolution in the group, we believe that overall evidence presented here justifies the reappraisal of Boissier's genus Megacaryon. This taxonomic evaluation seems more adequate to formally describe the diversity in Echium s.l. and is coherent with the current trends in the systematics of Boraginaceae (Chacón et al., 2016).

\section{Acknowledgements}

The authors wish to thank Laura Vivona for preparing the original drawing of Megacaryon orientale and Isabella Bettarini for assistance and company during the 2015 field trip to Turkey. Comments by two anonymous referees contributed to improve the first draft of the manuscript. 


\section{Disclosure statement}

No potential conflict of interest was reported by the authors.

\section{Funding}

Research grants from the University of Firenze to FS are acknowledged.

\section{Supplemental data}

Supplemental data for this article can be accessed here: http://dx.doi.org/10.1080/14772000.2017.1290707.

\section{References}

Bigazzi, M., \& Selvi, F. (2001). Karyotype morphology and cytogeography of Brunnera and Cynoglottis (Boraginaceae). Botanical Journal of the Linnean Society, 136, 365-378. Retrieved from: http://dx.doi.org/10.1006/boj1.2001.0453 (accessed 25 January.2017).

Binzet, R., Erkara, I. P., Özler, H., \& Pehlivan, S. (2014). Pollen morphology and systematical contribution of some Onosma (Boraginaceae) taxa distribution in Turkey. Plant Systematics and Evolution, 300, 2135-2146. doi:10.1007/s00606014-1030-Z

Böhle, U.-R., Hilger, H. H., \& Martin, W. (1996). Island colonization and evolution of the insular woody habit in Echium L. (Boraginaceae). Proceedings of the National Academy of Sciences U.S.A., 93, 11740-11745. Retrieved from: http:// www.pnas.org/content/93/21/11740.full.pdf (accessed 25 January 2017).

Boissier, P. E. (1875a). Plantarum orientalium novarum decas prima ex Florae Orientalis volumine tertio mox exituro excerta. Geneva: Georg. Retrieved from: http://dx.doi.org/ 10.5962/bhl.title.52107 (accessed 25 January 2017).

Boissier, P. E. (1875b). Flora Orientalis 4: 204. Geneva: Georg. Retrieved from: http://biodiversitylibrary.org/page/ 18114671 (accessed 25 January 2017).

Borchsenius, F. (2009). FastGap 1.2. Department of Biological Sciences, University of Aarhus. Published online at www. aubot.dk/FastGap_home.htm (accessed 4 April /2016).

Bramwell, D. (1973). Studies in the genus Echium from Macaronesia. Monographiae Biologicae Canariensis, 4, 71-72.

Burtt, B. L. (2001). Tournefort in Turkey (1701-1702). Karaca Arboretum Magazine, 6, 45-62.

Burtt, B. L. (2002). Tournefort in Turkey (1701-1702), part 2. Karaca Arboretum Magazine, 6, 137-146.

Buys, M. H. (2006). A morphological cladistic analysis of Lobostemon (Boraginaceae). South African Journal of Botany, 72, 383-390. Retrieved from: http://dx.doi.org/ 10.1016/j.sajb.2005.10.006 (accessed 25 January 2017).

Cafferty, S., \& Jarvis, C. E. (2004). Typification of Linnaean plant names in Boraginaceae. Taxon, 53, 799-805. Retrieved from: http://www.jstor.org/stable/4135454 (accessed 25 January 2017).

Cecchi, L., Coppi, A., Hilger, H. H., \& Selvi, F. (2014). Nonmonophyly of Buglossoides (Boraginaceae: Lithospermeae): Phylogenetic and morphological evidence for the expansion of Glandora and reappraisal of Aegonychon. Taxon, 63, 1065-1078. Retrieved from: https://doi.org/10.12705/635.4 (accessed 25 January 2017).
Cecchi, L., \& Selvi, F. (2009). Phylogenetic relationships of the monotypic genera Halacsya and Paramoltkia and the origins of serpentine adaptation in circum-mediterranean Lithospermeae (Boraginaceae): Insights from ITS and matK DNA sequences. Taxon, 58, 700-714. Retrieved from: http:// www.jstor.org/stable/27756939 (accessed 25 January 2017).

Chacón, J., Luebert, F., Hilger, H. H., Ovcinnikova, S., Selvi, F., Cecchi, L., ....Weigend, M. (2016). A revised infrafamilial classification of the borage family (Boraginaceae s.str.) based on a molecular phylogeny with an emphasis on the placement of some enigmatic genera. Taxon, 65, 523-546. doi: $10.12705 / 653.6$

Cohen, J. I. (2014). A phylogenetic analysis of morphological and molecular characters of Boraginaceae: Evolutionary relationships, taxonomy, and patterns of character evolution. Cladistics, 30, 139-169. doi:10.1111/cla.12036

Coppi, A., Selvi, F., \& Bigazzi, M. (2006). Chromosome studies in Mediterranean species of Boraginaceae. Flora Mediterranea, 16, 253-274. Retrieved from: http://www.herbmedit. org/flora/16-253.pdf (accessed 25 January 2017).

Doyle, J. J., \& Doyle, J. L. (1990). Isolation of plant DNA from fresh tissue. Focus, 12, 13-15.

Edmondson, J. R. (1979). Echium L. In P. H. Davis (Ed.), Flora of Turkey and the East Aegean islands (Vol. 6, pp. 317320). Edinburgh: University Press.

Fritsch, B. (1973). Karyologische Untersuchungen in der Gattung Echium L. Botaniska Notiser (Lund), 126, 450-458.

Galland, N. (1988). Recherche sur l'origine de la flore orophile du Maroc: Étude caryologique et cytogéographique. Travaux de l'Institute des Sciences de l'Universitè Mohammed V, Série Botanique, 35, 1-168.

Gibbs, P. E. (1972). Echium L. In T. G. Tutin, V. H. Heywood, N. A. Burges, D. M. Moore, D. H. Valentine, S. M. Walters, \& D. A. Webb (Eds.), Flora Europaea (Vol. 3,pp. 97-100). Cambridge: Cambridge University Press.

Greuter, W., Burdet, H. M., \& Long, G. (1984). Med-checklist (Vol. 1, pp. 82-87). Genève: Conservatoire et Jardin Botaniques.

Gürke, M. (1895). Megacaryon. In A. Engler \& K. Prantl (Eds.), Die natürlichen Pflanzenfamilien IV. Teil (3a, Lief. 114, p. 129, complete 1897). Leipzig: Engelmann. Retrieved from: http://biodiversitylibrary.org/page/32137045 (accessed 25 January 2017).

Heller, D., \& Heyn, C. C. (1986). Conspectus Florae Orientalis (Vol. 3, pp. 60-97). Jerusalem: Israel Academy of Sciences and Humanities.

Hilger, H. H. (2014). Ontogeny, morphology, and systematic significance of glochidiate and winged fruits of Cynoglosseae and Eritrichieae (Boraginaceae). Plant Diversity and Evolution, 131, 167-214. doi:10.1127/1869-6155/2014/0131-0080

Hilger, H. H., \& Böhle, U.-R. (2000). Pontechium: A new genus distinct from Echium and Lobostemon (Boraginaceae). Taxon, 49, 737-746. doi:10.2307/1223974

Johnston, I. M. (1924). Studies in the Boraginaceae. III. 1. The Old World genera of the Boraginoideae. Contributions from the Gray Herbarium of Harvard University, 73, 42-78. Retrieved from: http://www.jstor.org/stable/41764030 (accessed 25 January 2017).

Johnston, I. M. (1953). Studies in the Boraginaceae, XXV. A revaluation of some genera of Lithospermeae. Journal of the Arnold Arboretum, 34, 258-299. Retrieved from: http:// www.jstor.org/stable/43781861 (accessed 25 January 2017).

Katoh, K., Kuma, K.-I., Toh, H., \& Miyata, T. (2005). MAFFT version 5: Improvement in accuracy of multiple sequence 
alignment. Nucleic Acids Research, 33, 511518.doi:10.1093/nar/gki198

Katoh, K., \& Standley, D. M. (2013). MAFFT Multiple Sequence Alignment Software Version 7: Improvements in Performance and Usability. Molecular Biology and Evolution, 30, 772-780. doi:10.1093/nar/gki198

Kaul, M. K., \& Bindroo, B. B. (1984). Cytology of Onosma hispidum Wall. Chromosome Information Service, 36, 11-12.

Kimura, M. (1980). A simple method for estimating evolutionary rate of base substitutions through comparative studies of nucleotide sequences. Journal of Molecular Evolution, 16, 111-120. doi: 10.1007/BF01731581

Letz, R., Uhríková, A., \& Májovský, J. (1999). Chromosome numbers of several interesting taxa of the flora of Slovakia. Biologia (Bratislava), 54, 43-49. Retrieved from: http:// ibot.sav.sk/usr/Roman/docs/Papers/1999/Letz_et_al. _1999_Biologia.pdf (accessed 25 January 2017).

Levyns, M. R. (1934a). A revision of Lobostemon Lehm. and a discussion of the species problem. Botanical Journal of the Linnean Society, 49, 393-451. doi:10.1111/j.10958339.1934.tb00394.x

Levyns, M. R. (1934b). Cytology of Lobostemon and Echiostachys in relation to taxonomy. Annals of Botany, 48, 355362. Retrieved from: https://doi.org/10.1093/oxfordjournals. aob.a090450 (accessed 25 January 2017).

Linnaeus, C. (1753). Species Plantarum (Vol. 1, pp. 139-140). Holmiae: Laurentius Salvius. Retrieved from: http://dx.doi. org/10.5962/bhl.title.669

Liu, J.-X., Li, J.-Y., Zhang, Y.-L., \& Ning, J.-C. (2010). Pollen morphology of the tribe Lithospermeae of Boraginoideae in China and its taxonomic significance. Plant Systematics and Evolution, 290, 75-83. doi:10.1007/s00606-010-0350-x

Luque, T. (1984). Estudio cariologico de Boraginaceas españolas, II. Echium L. de España peninsular e Islas Baleares. Lagascalia, 13, 17-38. Retrieved from: http://bibdigital.rjb. csic.es/ing/Libro.php?Libro=2866\&Pagina $=18 \quad$ (accessed 25 January 2017).

Markova, M. (1983). In A. Löve (Ed.) IOPB chromosome number reports LXXVIII. Taxon, 32, 140. Retrieved from: http:// www.jstor.org/stable/1219873 (accessed 25 January 2017).

Mansion, G., Selvi, F., Guggisberg, A., \& Conti, E. (2009). Origin of Mediterranean insular endemics in the Boraginales: Integrative evidence from molecular dating and ancestral area reconstruction. Journal of Biogeography, 36, 12821296. doi:10.1111/j.1365-2699.2009.02082.x

Page, R. D. M. (1996). TreeView: An application to display phylogenetic trees on personal computers. Bioinformatics, 12, 357-358. Retrieved from: https://doi.org/10.1093/bioinfor matics/12.4.357 (accessed 25 January 2017).

Reille, M. (1992). Pollen et spores d'Europe et de l'Afrique du Nord. Marseille: Éditions du Laboratoire de botanique historique et palynologie.

Reille, M. (1995). Pollen et spores d'Europe et d'Afrique du Nord, Supplément 2. Marseille: Éditions du Laboratoire de botanique historique et palynologie.
Retief, E., \& van Wyk, A. E. (1997). Palynology of southern African Boraginaceae: The genera Lobostemon, Echiostachys and Echium. Grana, 36, 271-278. Retrieved from: http://dx.doi.org/10.1080/00173139709362616 (accessed 25 January 2017).

Ronquist, F., \& Huelsenbeck, L. P. (2003). MrBayes 3: Bayesian phylogenetic inference under mixed models. Bioinformatics, 19, 1572-1574. Retrieved from: https://doi.org/10.1093/bio informatics/btg180 (accessed 25 January 2017).

Seibert, J. (1978). Fruchtanatomische Untersuchungen an Lithospermeae (Boraginaceae). Dissertationes Botanicae, 44. Vaduz: Cramer.

Selvi, F., \& Bigazzi, M. (2002). Chromosome studies in Turkish species of Nonea (Boraginaceae): The role of polyploidy and descending dysploidy in the evolution of the genus. Edinburgh Journal of Botany, 59, 405-420. doi:10.10M/ S0960428602000240

Simmons, M. P., \& Ochoterena, H. (2000). Gaps as characters in sequence-based phylogenetic analyses. Systematic Biology, 49, 369-381. doi:10.1093/sysbio/49.2.369

Swofford, D. L. (2000). PAUP* 4.0. Phylogenetic Analysis Using Parsimony (and other methods) vers. 4.0. Sunderland, MA: Sinauer. Retrieved from: http://paup.scs.fsu.edu/ Cmd_ref_v2.pdf (accessed 25 January 2017).

Teppner, H. (1996). Remarks to the Onosma species O. bourgaei, O. spruneri and O. stellulata (Boraginaceae) offered. In Samentauschverzeichnis 1996 (pp. 33-39). Graz: Botanischer Garten des Institutes für Botanik der Universität. Retrieved from: https://static.uni-graz.at/fileadmin/_Persoen liche_Webseite/teppner_herwig/Publicationen/teppner1996-onosma-bourgaei-spruneri-stellulata.pdf (accessed 25 January 2017).

Tournefort, J. (1717). Relation d'un Voyage du Levant 2. Lyon: Anisson et Posuel. Retrieved from: http://biodiversityli brary.org/page/40454467 (accessed 25 January 2017).

Weigend, M., Gottschling, M., Selvi, F., \& Hilger, H. H. (2009). Marbleseeds are gromwells - Systematics and evolution of Lithospermum and allies (Boraginaceae tribe Lithospermeae) based on molecular and morphological data. Molecular Phylogenetics and Evolution, 52, 755-768. Retrieved from: http://dx.doi.org/ 10.1016/j.ympev.2009.05.013 (accessed 25 January 2017).

Weigend, M., Luebert, F., Selvi, F., Brokamp, G., \& Hilger, H. H. (2013). Multiple origins for Hounds tongues (Cynoglossum L.) and Navel seeds (Omphalodes Mill.) - the phylogeny of the borage family (Boraginaceae s.str.). Molecular Phylogenetics and Evoution, 68, 604-618. Retrieved from: doi:10.1016/j.ympev.2013.04.009

Weigend, M., Selvi, F., Thomas, D. C., \& Hilger, H. H. (2016). Boraginaceae. In J. W. Kadereit \& V. Bittrich (Eds.), The families and genera of vascular plants (Vol. 14, pp. 41101). Basel: Springer. doi:10.1007/978-3-319-28534-4

Associate Editor: Elliot Shubert 